\title{
MUC16 Gene
}

National Cancer Institute

\section{Source}

National Cancer Institute. MUC16 Gene. NCI Thesaurus. Code C71018.

This gene is involved in both cellular adhesion and the maintenance of mucosal surfaces. 